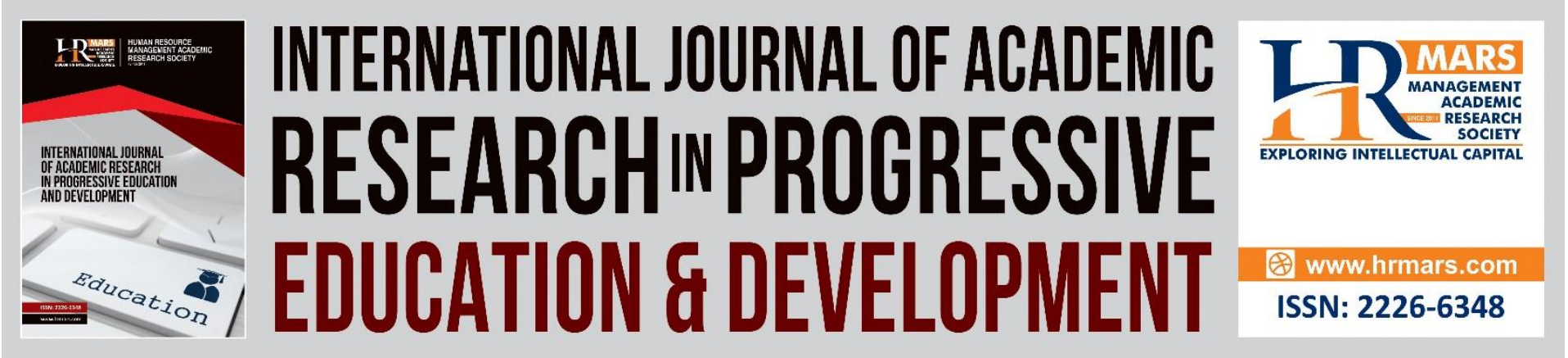

\title{
Tracing Effectiveness and Challenges in Using Online Tools to Enhance Vocabulary Language Learning: A Review
}

Sharvin Devi Mohan Raw, Hanita Hanim Ismail

To Link this Article: http://dx.doi.org/10.6007/IJARPED/v10-i3/10756

DOI:10.6007/IJARPED/v10-i3/10756

Received: 07 July 2021, Revised: 10 August 2021, Accepted: 25 August 2021

Published Online: 18 September 2021

In-Text Citation: (Raw \& Ismail, 2021)

To Cite this Article: Raw, S. D. M., \& Ismail, H. H. (2021). Tracing Effectiveness and Challenges in Using Online Tools to Enhance Vocabulary Language Learning: A Review. International Journal of Academic Research in Progressive Education and Development, 10(3), 941-955.

Copyright: (c) 2021 The Author(s)

Published by Human Resource Management Academic Research Society (www.hrmars.com)

This article is published under the Creative Commons Attribution (CC BY 4.0) license. Anyone may reproduce, distribute, translate and create derivative works of this article (for both commercial and non-commercial purposes), subject to full attribution to the original publication and authors. The full terms of this license may be seen

at: http://creativecommons.org/licences/by/4.0/legalcode

Vol. 10(3) 2021, Pg. 941 - 955

http://hrmars.com/index.php/pages/detail/IJARPED

JOURNAL HOMEPAGE

Full Terms \& Conditions of access and use can be found at http://hrmars.com/index.php/pages/detail/publication-ethics 


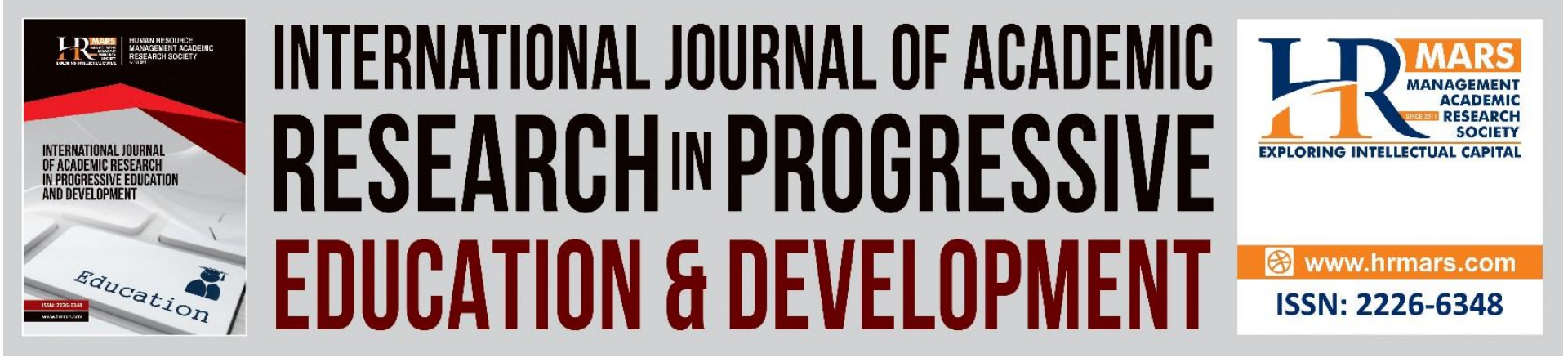

\title{
Tracing Effectiveness and Challenges in Using Online Tools to Enhance Vocabulary Language Learning: A Review
}

\author{
Sharvin Devi Mohan Raw \\ SK Bukit Tadom, Kampung Bukit Tadom, 42700 Banting, Selangor. \\ Email: p105811@siswa.ukm.edu.my \\ Hanita Hanim Ismail \\ Faculty of Education Universiti Kebangsaan Malaysia \\ Email: hanitaismail@ukm.edu.my
}

\begin{abstract}
Technology has brought up tremendous changes in the education field. Technology has become a powerful platform in the ever-changing pedagogical approaches which meet the current context where learning could be done using various technology tools instead of relying on paper and pen approach. Newly, online tools have become educators' focus as they are interesting and easily available for language teaching and learning around the world. This review addressed two research questions, namely how online tools enhance students' English vocabulary learning and what are the challenges faced by the English learners and teachers in using online tools. Thirty-one studies from the year 2015 to 2021 were shortlisted from the Google Scholar and Educational Resources Information Centre (ERIC) databases based on the two review questions. Therefore, this paper reviewed 23 relevant published studies on the teaching and learning of English vocabulary through various online tools and 8 pertinent past studies on the challenges faced by the educators and learners in using online tools in a language classroom. This review explored the effectiveness of online tools in enhancing vocabulary learning in the language classroom under five key concepts namely vocabulary knowledge and retention, motivation in learning, active participation, immediate feedback and self-regulated learning. This study further revealed that the educators and learners are facing numerous challenges in using online tools in the classroom. This study proposes further researches on overcoming the barriers of using online tools to enhance the learners' language learning in par with the current technology advancement.
\end{abstract}

Keywords: Online Tools, Technology, Effectiveness, Challenges, Vocabulary Language Learning 


\section{Introduction}

As an international language and the United Nations' official language, English has demonstrated its importance as a means of worldwide communication. English is also known as the international language around the entire world where it is being used as the main medium of communication to connect people from various parts of the world. Every learner in Malaysia is required to learn and master two main languages which are Bahasa Malaysia and English as stated in the Malaysian Education Blueprint 2013-2025 (Ministry of Education, 2013). This further explains in the National Education Policy where in Malaysia, as mentioned in article 152, English is known as the second language which is a required language that needs to be learnt after the national language which is Bahasa Melayu (Ministry of Education, 2017). The two crucial actions taken by the government to enhance English language learning is the extension of English learning hours in national secondary schools for a week from 240 minutes to 270 minutes and making English a must-pass subject in SPM (Ministry of Education, 2013). Besides, the implementation of two new programs under 'Uphold Bahasa Melayu (Malay Language) and strengthen the English Language' policy in the Malaysia Education Blueprint 2013-2025, which are the Highly Immersive Programme and the Dual Language Programme (DLP) in year 2016 further proves the governments' concern about the significance of English in Malaysia (Ministry of Education Malaysia, 2017).

As a result, most schools, beginning at the elementary level, prepare children to master English. Earlier exposure to English would ensure better language proficiency. This is due to the fact that in elementary school, children's brains are still developing (Jasińska \& Petitto, 2018). Pupils as early as seven years old start learning English formally in Malaysian classrooms. Vocabulary learning is the most important component of learning any language including the learning of English as a second language (Ying, 2010). Learning vocabulary is an important skill that aids the learning of the other two main skills which are reading and writing. According to Graves and Watts-Taffe (2008), in order to build the high reading levels necessary for success in school and beyond, pupils' vocabulary knowledge should be improved first. Dalton and Grisham (2011) believe that digital tools and media that are widely available in almost every school can improve pupils' learning of vocabulary.

According to Nomass (2013), the fast rise of ICT (Information and Communication Technologies) has challenged teachers' style of thinking in order to improve the worldwide picture of education. In fact, ICT has altered the educational environment (Azmi, 2017). Learning has undergone a revolution as a result of the fast growth of ICT. New teaching and learning methods and media have resulted from technological advancements in education. Teachers and students are now facing new obstacles in the modern learning environment, mainly IT (Information Technology) which can be accessed via mobile devices (Hernandez, 2017). Traditional methods of teaching vocabulary are no longer preferred by the pupils, causing teachers to utilise available online tools to somehow narrow the educational gap to improve pupils' vocabulary learning for their better mastery of English language.

The rapid development of technology has increased the number of online tools available that can be used to cater language teaching and learning. Online tools that can be used in language teaching in the classroom has been categorised based on internet-based tools that are now available and free to use under 12 categories (Son, 2011). Based on the categorisation of online tools by Son (2011), Learning Management Systems/ Content Management Systems such as Moodle, Drupal, Joomla are tools to plan, execute and evaluate language learning. Second category is communication and tools such as Messenger, Gmail 
and Skype used for voice texting and video conferences. Next category is Live and Virtual World and tools such as ActiveWorld, WiZiQ and Wimba Classroom are to conduct live meetings. Fourth category is social networking and bookmarking in which Facebook, Tweeter and Myspace are tools for saving and sharing information. Next, Edmodo, Penzu and WordPress.com, are tools for collaborative language learning categorised under Blogs and wikis. Besides, for the presentation category, tools like Prezi, Animoto and SlideRocket can be used to present information in a creative way. The seventh category is resource sharing in which Google Docs, Slideshare, YouTube can be used as tools to share information. Website creation is the eighth category that helps to create your own websites for learning using tools like Webnode, SnapPages and KompoZer. Following that is Web search engines. This category of online tools such as Yahoo, Bing and Google are to search information. The eleventh category of online tools by Son (2011) is dictionaries and concordancers. Under this category, tools like YourDictionary.com, Merriam Webster Online and Forvo are used for language reference. The last category is utilities. This category tools such as Doodle, Storybird and SurveyMonkey are for active language activities.

There are many previous studies that have been discussed and reported on using countless online tools in language learning that have been published but so far, there are a few of recent studies on how effective online tools are in vocabulary learning among English learners on whole and the challenges faced by the English learners and teachers in using online tools in the classroom. Therefore, this review addressed two research questions: 1 ) How do online tools enhance students' English vocabulary learning? 2) What are the challenges faced by the English learners and teachers in using online tools?

\section{Methodology}

Two databases were used to conduct the search for references for this study. The procedure of finding the article began with a search in Google Scholar and Education Resources Information Centre databases (ERIC). To begin, broad query phrases were used to compile a list of essential and related research articles. The study selection criteria which were extracted from the review questions were 'online tools in learning vocabulary', 'usefulness of online tools to teach vocabulary', 'challenges in using online tools in learning' and 'challenges of using online tools in classroom'. The two databases used to search for research studies or articles written in English published in the year 2015 to 2021 were Google Scholar and Educational Resources Information Centre (ERIC). The procedure of inserting keywords for the search of articles in Google Scholar and ERIC were different. While using Google Scholar to search for articles regarding effectiveness of technology tools in enhancing students' English vocabulary learning, the keywords "online tools" (or the terms "digital tools" or "technology tools" or "web-based learning tools" or "e learning tools) and "vocabulary teaching and learning" were entered. Then, in order to narrow down the articles to relevant articles, the year of publication was set to 'Since 2015', which enables the search of articles that are published within the recent five years (2015 to 2021). Next, under the search criteria 'with the exact phase' under the 'advanced search' function, the phrase ' online tools in vocabulary teaching and learning ' was entered to avoid the articles which were related to English language teaching but without the term 'vocabulary' appearing in the search results. Whereas, for ERIC searches, the keyword 'online tools and challenges in classroom' was entered. Then, two aspects were refined: the 'publication date' and 'descriptor'. For 'publication date', 'since 2015 (last 5 years)' was chosen whereas for 'descriptor', 'English 
(Second Language) was chosen to avoid articles related to online tools in teaching and learning of other subject areas such as engineering or business.

\section{Literature Review Findings and Discussions Effectiveness of Online Tools in Enhancing Vocabulary Learning}

Online tools are proved to be useful and effective in enhancing learners' language learning as well as teachers teaching methodology (Kessler, 2018). This review specifies the effectiveness of online tools in learning that focuses on vocabulary. The usefulness of online tools in improving learners' vocabulary learning are numerous and this review has revealed how online tools are improving the learners' vocabulary learning via several main concepts. Effectiveness of online tools in enhancing vocabulary learning among English Language learners are reviewed based on several past studies under the five main concepts namely vocabulary knowledge and retention, motivation in learning, active participation, immediate feedback and self-regulated learning. In general, online tools act as a mediator to increase learners' vocabulary knowledge and retention; increase learners' motivation in learning; increase active participation among the learners; provide immediate feedback and promote self-regulated learning. All these factors help the learners to acquire the desired amount of vocabulary to develop their language proficiency and each will be discussed below.

\section{Vocabulary Knowledge and Retention}

Knowledge of vocabulary is an important part of language ability. The number of known words by the learners and how well they know them in the sense of the quality or depth of word knowledge are related to the student's listening, speaking, reading and writing skills in the target language as well as their overall English language proficiency (Elgort, 2018). According to Ghobadi and Taki (2018), online tools can provide significant benefits to learners in developing their vocabulary knowledge by helping them to acquire new vocabulary items. The study consisting of seventy-seven male EFL Saudi students at Imam Mohammed Ibn Saud Islamic University at Deanship of Preparatory Programs conducted by Al Shra'ah (2021) shows that using Kahoot as an instructional strategy had a positive effect on developing student's vocabulary acquisition after viewing the statistically significant differences in their post-tests.

Online tools enhance the performance of language learners. According to Al Buraiki and Al-Hamdani (2017) study on the effectiveness of online tools on the performance of the vocabulary test of Omani EFL learners that consists of twenty-four in the experimental group and twenty-three in the control group shows that experimental group obtained higher marks in the vocabulary post-test as the online tool facilitate the learning of new vocabulary through memorisation and retention. Quiroz (2021) investigates the effects of online tools in improving English vocabulary learning where he observes that there is improvement regarding English vocabulary knowledge from the increase in results of an intervention. Teaching using online tools outperformed traditional instruction in terms of overall accomplishment as well as the learning of a vocabulary item according to the post test results from a study conducted by Dehham (2021) in fourth-grade preparatory school for boys in the province of Karbala. Online tools demonstrated to provide an efficient mastery of words. This is because digital tools provided various excellent psychological and cognitive circumstances that had an effect on short-term memory and also on long-term memory (Ciaramella, 2017).

Luik (2019) conducts a study using a web-based tool, Kahoot in acquiring vocabulary competence and the results obtained from the participants before and after playing Kahoot! 
during a vocabulary lesson. The participants learned new words as well as synonyms for some vocabulary. The EFL students were able to attain their aim of not only knowing the meaning of the words, but also how to utilise them in various contexts, by playing Kahoot! 51 students from 1st year at South Korean University were involved in a study conducted by Taylor and Reynolds (2018) to assess the impact Kahoot had on their vocabulary retention by. Kahoot promotes vocabulary retention while also establishing an optimistic learning atmosphere and a meaningful learning experience, according to the findings. In general, the use of online tools reinforces vocabulary instruction resulting in an increase of vocabulary acquisition through vocabulary retention. So, online tools are effective to improve vocabulary knowledge and retention.

\section{Motivation in Learning}

Education aims at creating learning environments that encourage pupils to be motivated and learn. The value of the positive and lively learning environment in motivating students in school cannot be overstated. As stated by Chen et al (2018), the learning environment influences students' learning achievement. Learners learn in a better way when they are provided with a positive learning environment that can motivate them to learn. According to Plump and LaRosa (2017), online tools provide a positive learning environment in the classroom that encourage idea exploration and make learning more enjoyable that eventually lead the learners to feel motivated in enhancing their understanding of what is being taught. Learners' motivation is determined by why they want to learn something, how long they are willing to stick with it, and how hard they are willing to work (Lee, 2012). Students will find the class more fascinating and motivated to study if their teachers use more interesting teaching methods. Baez et al (2017) agrees that in regards to students' mentalities, most learners felt spurred and excited about utilizing online platforms as it urges them to carry out their tasks better while permitting them to acquire the confidence to foster their linguistic abilities.

Online tools provide a positive learning environment for the learners as well as motivate them to learn vocabulary which eventually enhances their vocabulary knowledge. This is reiterated by Mansur and Fadhilawati (2019) in their study where the use of Kahoot application was able to improve students' English Vocabulary achievement that eventually increased their vocabulary learning result from 59.23 to 84.58. Similarly, Huei et al (2021) performs research on Quizizz in improving vocabulary achievement among primary English as Secondary Language (ESL) pupils in rural schools. The finding revealed that Quizizz was able to arouse a positive learning environment and provides an engaging learning environment by recapping words which helps the pupils to enhance their vocabulary learning. Masoud et al. (2020) prove that web-based learning (i.e. the use of Kahoot) is effective in enhancing vocabulary learning of the experimental group, proving that web-based tools enhance students' motivation in learning new words. Rakangthong and Yimwilai (2020) found that using digital online tools improved students' vocabulary understanding since it made the vocabulary learning process easier and more pleasant. It was also found that digital online tools are beneficial not just for academic objectives, but also for motivational objectives, since they provide engaging vocabulary tasks, incentive, and a pleasant setting. In a study on $33 \mathrm{EFL}$ students from three different levels of English (B2, C1 and C2 on the CEFR scale) to check the effectiveness of an online tool in improving vocabulary learning, Vurdien (2020) proves that the competitive aspect of the quizzes via online tool boosted the students' interest in 
vocabulary recall and it is an efficient tool for establishing a learning environment and inspiring students to acquire lexicon in a more dynamic and engaging way. Thus, online tools are effective to create a positive and fun vocabulary learning environment that motivates the learners to learn vocabulary.

\section{Active Participation}

Active learning is the polar opposite of passive learning: it is learner-centered rather than teacher-centered, and it entails more than just listening (Croker \& Kamegai, 2017). Active learning necessitates active engagement between learners where they must be able to do and think synchronously. Active learning creates learning environments that are centred on the students and designed to encourage interaction and participation. They are intended to reduce the distance between the teacher and the student, allow collaborative learning activities, and improve teaching techniques (Chiu \& Cheng, 2016; Metzger, 2015).

Learning via online tools has the potential to create an engaging learning environment that encourages active involvement in the classroom (Plump \& LaRosa, 2017). According to Khan et al. (2017), there are various digital tools available to actively engage students in the courses and improve learning. Online tools play its role to promote active learning among the language learners which eventually enhances their vocabulary learning. This is supported by Sanosi (2018) who records substantial improvement in vocabulary post-test because online tools are great tools for active learning in the classroom or even outside of it when it comes to acquiring vocabulary. Another study that yields the same result was conducted by Hadijah et al. (2020) which confirms that digital tools improve the learners' vocabulary learning as it attracts the students' attention in learning which eventually leads to their active participation in the classroom to learn new sets of words. Students' engagement in the classroom may improve as a result of active learning activities in classrooms that were designed to suit the current instructional practice and active learning has a favourable effect on pupils' capacity to recall and comprehend new information such as vocabulary (Plump \& LaRosa, 2017). In agreement with Kent (2019), the use of a variety of digital technologies in the classroom has been proved to increase active learning and student engagement with the topic. It gives a technologically interactive learning opportunity for all students, which is appreciated, as it helps pupils focus on the material and improves their vocabulary knowledge. Hence, online tools are effective to foster active learning of vocabulary among the English language learners.

\section{Immediate Feedback}

Role of online tools in the feedback process of learning vocabulary is explored by Nurhasanah (2020), which indicated that online tools have made it possible for teachers to give learners individual feedback and guidance in learning vocabulary. Giving and/or writing comments on students' work was always a difficult and time-consuming process for most teachers before the inclusion of technology into education (Manegre \& Sabiri, 2020). Teaching using online tools helps in providing feedback and makes the class interesting, fun and informative (Elmahdi et al., 2018). Formative assessment conducted in the presence of digital tools in a vocabulary learning classroom provides room for immediate feedback. Yarahmadzehi and Goodarzi (2020) conducts a study on Iranian pre-intermediate EFL learners in an experimental research indicating that learners were able to retain more information on vocabulary and perform better in the post-test compared to the pre-test. In this study, the 
experiment group underwent a formative assessment using Socrative and recorded improvement in their vocabulary learning.

Apart from the appealing atmosphere of mobile testing applications and its faster process of test-taking, mobile-based formative assessment (e.g. Kahoot) offers an advantage over paper-based assessments, which takes longer time for teachers to correct papers and return feedback to students. Because they are able to see immediate results from the, pupils try harder on subsequent assessments. In a study by Nurhasanah (2020) on the eleventh grade students of SMA Muhammadiyah 1 Ponorogo, there is a significant difference in vocabulary mastery scores between students who used Socrative application and students who utilised paper based assessment for formative assessment. Students who utilised the Socrative app for formative assessment received a higher grade than those who did not. In consequence, online tools are effective in giving instant feedback in vocabulary learning for further improvement.

\section{Self -regulated Learning}

Learner's autonomy is where the learners learn a language at their own initiative and responsibility which paves a platform for their self-regulated learning. Learner's autonomy in language acquisition, according to Benson (2007), is the learner's capability to undertake responsibility for the learning outcomes and the language. Language learning procedures necessitate students' active engagement in the learning process, with the learning objective always being the development of learner autonomy. Hence, improvement of learners' autonomy is viewed as one of the significant and main considerations in the accomplishment of language learning (Ngoc Nguyen \& Nguyen, 2020). Even though learner's autonomy in learning English helps the learners to acquire the language, teachers play a vital role in preparing the learners towards taking charge of their own learning. As stated by Pershukova et al. (2020), learners don't always accept responsibility for their own learning and don't always find it simple to reflect on the process and that is where the teachers must give students with the tools and opportunities they require. It is challenging to educate students to be masters of their own learning since both the instructor and the students must swap roles in order to establish a healthy self-regulated learning environment.

Self-regulated learning describes how students take charge of their own learning and develop techniques to support it and this process develops them to be independent learners (Yot-Domínguez \& Marcelo, 2017). Self-regulated students are conscious of their own learning process and are aware of what they require for learning as well as what they should do to improve their academic performance. According to Kingsbury (2015), the capacity of pupils to learn without the assistance of teachers has an impact on their academic progress. 2.0 social software technologies, such as communication tools, resource and experience sharing tools, and even social network tools, offer a lot of promise to help students regulate their learning. (Valentín et al., 2013). Technologies aid in the development of self-regulation learning to enhance language learning. This is proven by Waluyo (2018) on 68 First-year students on their vocabulary acquisition using Socrative where the findings confirmed that formative evaluation using Socrative enhances the learners' vocabulary acquisition through the use of self-regulated learning methods. Setiawan and Wiedarti (2020) also reiterate that the learners are able to learn vocabulary independently with the aid of digital tools. Formative evaluation that precedes with instant feedback after the pre-test on their vocabulary acquisition in the classroom using digital tools provides room for the learners to do self- 
reflection and self -assessment that leads to self-regulated learning. Students evaluate their learning at this step and develop justifications for the outcomes that help them to do better in their post test that eventually paves a way for vocabulary acquisition to take place. Therefore, online tools are effective in creating self-regulated vocabulary learning among English language learners.

\section{Challenges of using Online Tools in Language Classroom}

In this digital world, using online tools in the classroom is critical for students to acquire and apply the necessary 21st century competencies. Many studies suggest that online tools have a lot of promise for being used in language classrooms (Alkamel \& Chouthaiwale, 2018; Hajebi et al., 2018). As a result, exploring the concerns and problems on the use of online tools in teaching and learning can help instructors in becoming effective technology users (Hernandez, 2017). While there are numerous past studies that acknowledge the significance of online tools in learning English Kent (2019), there are some on identifying the challenges faced by the teachers and learners in using online tools in a language learning classroom. Some of the challenges faced by the teachers in technology-based classrooms is the teachers' lack of computer skills (Hernandez, 2017; Prasangani, 2019; Singhavi \& Basargekar, 2019). These researchers add on other types of challenges, such as the lack of financial support, poor internet connection, epileptic power supply, limited access to computer facilities, lack of pedagogical models, inadequate time for the teachers, lack of flexibility in implementing ICT and teachers' willingness to use ICT in the classroom.

When discussing the provision of ICT training for teachers, Azmi (2017) reveals a lack of proper training and planning as hindrance for using online tools in the classroom. In order to maintain the smoothness and effectiveness of a lesson, the teacher has to pre plan the teaching by exploring the online tool that is intended to be used in the language lesson. Not all educators are well versed in using technologies and when there is nor being provided with sufficient training, the lesson that integrates online tools fails to achieve the lesson objectives. Furthermore, inadequate ICT tools and failure to comply with the schools' regulations are the two challenges in using technology-based teaching via online tools in classroom teaching and learning (Razak et al., 2019). Some schools with rigid rules are not allowing teaching and learners to use all types of online tools, especially learning via social media. The selection of online tools is very limited and has to adhere to rigid rules.

Ghavifekr et al (2016) also identifies having sufficient ICT tools in rural schools is one of the challenges where basic technology tools such as computers are lacking causing the pupils to be illiterate in using ICT. Most students were incapable of operating digital gadgets and learning language using online tools was far from possible. When the students' perspective was investigated, Hadijah et al (2020) claims that the learners showed a lack of self-confidence when playing Kahoot. Some students get disappointed whenever they get the lowest score and their names are displayed on the leader's board in Kahoot! alongside with other high achievers. Despite the scores, some students become less confident because they have limited knowledge in using online tools as not all students are trained the same way. In a study by Waer (2021) who explores learners' attitudes toward Quizizz usage, she found out that the students who used Quizizz in learning vocabulary, were excited and enjoyed their learning session, despite the poor internet access. Internet access is vital to operate all the online tools and it is almost impossible to conduct the lesson without a proper internet connection. 


\section{Conclusion}

This review revealed the answers for the two research questions. As for RQ1 (How do online tools enhance students' vocabulary learning?), a review on past studies indicated that using technology is effective in enhancing teaching and learning of vocabulary where online tools are advantages to improve vocabulary knowledge and retention; create a positive and fun vocabulary learning environment that motivates the learners to learn vocabulary; foster active learning of vocabulary among the English language learners; give instant feedback in vocabulary learning for further improvement; and create self-regulated vocabulary learning among English language learners. As per RQ2 (What are the challenges faced by the learner's and teachers in using online tools?), past studies showed that time management, technical issues, adaptability struggle and computer illiteracy among teachers and learners are the possible challenges of using online tools in a language classroom.

This review was impeded by two aspects. First of all, university students and teachers were chosen as research participants for most of the studies in this review on the effectiveness of technology in teaching and learning of vocabulary. As such, further studies can be done on investigating the effectiveness of using technology in teaching and learning of vocabulary among primary school students since online teaching and learning is now increasingly applied in primary and secondary education. Another limitation identified is the challenges in using technology in the classroom which are mostly focused on the teachers where learners might also face these challenges and problems in using technology in the classroom. Most of the studies focus on the foreign context where some challenges might not be applicable in Malaysian classrooms as the infrastructure of every country differs. Future studies should also include the challenges faced by the learners in using technology in learning in Malaysia.

This review evidently showed that digital tools are effective in teaching vocabulary. Most of the past studies reviewed in this paper are conducted in foreign context which focuses on tertiary level learners and there is a lack of studies in Malaysian context especially among young learners to prove the effectiveness of digital tools in enhancing vocabulary learning. Teaching English lessons via digital tools in Malaysia might not be as effective as in other countries and it needs to be identified. Therefore, this study opens up a new dimension for further researchers to fill in the gap by carrying out researches that based on Malaysian young learners' and teachers' perceptions of using digital tools in enhancing vocabulary learning by considering the five main concepts which are vocabulary retention, learning environment, active participation, self-regulated learning and instant feedback.

For both instructors and students, dealing with the problems of digital learning may be disappointing and stressful. Based on the review, time management, technical issues, adaptability struggle and computer literacy among teachers and learners are the possible challenges of using online tools in a language classroom. Yet, in order to maximise the potential of ICT and provide students with the skills they need to be lifelong language learners, instructors and students' confidence in using technology must be boosted by providing them with the necessary electronic equipment, training, and time resources. There is limited research on possible ways of solving the problems that occur to enhance the students' learning via online tools. The future researchers may fill in the research gap by exploring studies on overcoming the barriers of using online tools to enhance the learners' language learning stresses on maximising necessary electronic equipment, training, and time resources. 


\section{References}

Al Buraiki, M. S. M., \& Al-Hamdani, D. (2017). Examining the effectiveness of using online activities in learning english vocabulary. In 2017 6th International Conference on Information and Communication Technology and Accessibility (ICTA) (pp. 1-4). IEEE. https://doi.org/10.1109/ICTA.2017.8336062

Alkamel, M. A. A., \& Chouthaiwale, S. S. (2018). The use of ICT tools in English language teaching and learning: A literature review. Veda's Journal of English Language and Literature, 5(2), 29-33. Retrieved from http://joell.in/wp-content/uploads/2018/04/2933-THE-USE-OF-ICT-TOOLS-IN-ENGLISH-LANGUAGE.pdf

Al Shra'ah, M. H. (2021). The Effect of Kahoot on Developing EFL Saudi Students' Vocabulary مجلة . Acquisition, Reading Comprehension, and their Attitudes towards such a Strategy الجامعة الإسلامية للدراسات التربوية والنفسية, 29(1).

http://dx.doi.org/10.33976/iugjeps.v29i1.7480

Azmi, N. (2017). The benefits of using ICT in the EFL classroom: From perceived utility to potential challenges. Journal of Educational and Social Research, 7(1), 111. http://dx.doi.org/10.5901/jesr.2017.v7n1p111

Baez, M. C., Mosquera, J. J. M., \& Stobäus, C. D. (2017). Initial Motivation and Pedagogical Support of Physical Education Students of Unipampa-RS. Creative Education, 8(09), 1401. https://doi.org/10.4236/ce.2017.89098.

Benson, P. (2007). Autonomy in language teaching and learning. Language Teaching, 40(1), 21-40. https://doi.org/10.1017/S0261444806003958

Chen, C. H., Liu, J. H., \& Shou, W. C. (2018). How competition in a game-based science learning environment influences students' learning achievement, flow experience, and learning behavioral patterns. Journal of Educational Technology \& Society, 21(2), 164-176. Retrieved from http://www.jstor.org/stable/26388392

Chiu, P. H. P., \& Cheng, S. H. (2016). Effects of active learning classrooms on student learning: a two-year empirical investigation on student perceptions and academic performance. Higher Education Research \& Development, 36(2), 269-279. https://doi.org/10.1080/07294360.2016.1196475

Ciaramella, K. E. (2017). The effects of Kahoot! on vocabulary acquisition and retention of students with learning disabilities and other health impairments. Rowan University.

Croker, R., \& Kamegai, M. (2017). Active learning in the Japanese high school English classroom: How far have teachers already come. ACADEMIA Literature and Language, 103, 63-77. Retrieved from https://core.ac.uk/reader/236163740

Dehham, S. H. (2021). Iraqi EFL Students' Ability in Acquiring English Vocabulary by Peer Instruction Technology. Turkish Journal of Computer and Mathematics Education (TURCOMAT), 12(9), 1634-1639. https://doi.org/10.17762/turcomat.v12i9.3559

Dalton, B., \& Grisham, D. L. (2011). eVoc Strategies: 10 Ways to Use Technology to Build Vocabulary. The Reading Teacher, 64(5), 306-317. https://doi.org/10.1598/RT.64.5.1

Elgort, I. (2018). Teaching/Developing Vocabulary Using ICTs and Digital Resources. The TESOL Encyclopedia of English Language Teaching, 1-15. https://doi.org/10.1002/9781118784235.eelt0735

Elmahdi, I., Al-Hattami, A., \& Fawzi, H. (2018). Using Technology for Formative Assessment to Improve Students' Learning. Turkish Online Journal of Educational Technology-TOJET, 17(2), 182-188. Retrieved from https://eric.ed.gov/?id=EJ1176157 
Taylor, B., \& Reynolds, E. (2018). Building vocabulary skills and classroom engagement with Kahoot. In 26th Korea TESOL international conference (p. 89). Retrieved from https://koreatesol.org/sites/default/files/pdf_publications/KOTESOL.2018Extended.Summaries..pdf\#page $=89$

Ghavifekr, S., Kunjappan, T., Ramasamy, L., \& Anthony, A. (2016). Teaching and Learning with ICT Tools: Issues and Challenges from Teachers' Perceptions. Malaysian Online Journal of Educational Technology, 4(2), 38-57. Retrieved from https://eric.ed.gov/?id=EJ1096028

Ghobadi, S., \& Taki, S. (2018). Effects of Telegram stickers on English vocabulary learning: Focus on Iranian EFL learners. Research in English language pedagogy, 6(1), 139-158. https://dx.doi.org/10.30486/relp.2018.538824

Graves, M. F., \& Watts-Taffe, S. (2008). For the love of words: Fostering word consciousness in young readers. The Reading Teacher, 62(3), 185-193. https://doi.org/10.1598/RT.62.3.1

Hadijah, H., Pratolo, B. W., \& Rondiyah, R. (2020). Interactive game "Kahoot!" as the media of students' vocabulary assessment. Journal on English as a Foreign Language, 10(1), 84-102. Retrieved from http://e-journal.iainpalangkaraya.ac.id/index.php/jefl/article/view/1670

Hajebi, M., Taheri, S., Fahandezh, F., \& Salari, H. (2018). The role of Web-based language teaching on vocabulary retention of adult pre-intermediate EFL learners. Journal of Language Teaching and Research, 9(2), 372-378. http://dx.doi.org/10.17507/jltr.0902.20

Hernandez, R. M. (2017). Impact of ICT on Education: Challenges and Perspectives. Journal of Educational Psychology-Propositos y Representaciones, 5(1), 337-347. http://dx.doi.org/10.20511/pyr2017.v5n1.149

Huei, L. S., Yunus, M. M., \& Hashim, H. (2021). Strategy to Improve English Vocabulary Achievement during Covid-19 Epidemic. Does Quizizz Help?. Journal of Education and e-Learning Research, 8(2), 135-142. https://doi.org/10.20448/journal.509.2021.82.135.142

Jasińska, K. K., \& Petitto, L. A. (2018). Age of bilingual exposure is related to the contribution of phonological and semantic knowledge to successful reading development. Child development, 89(1), 310-331. https://doi.org/10.1111/cdev.12745

Kent, D. (2019). Technique efficacy when using a student response system in the reading classroom.

Kessler, G. (2018). Technology and the future of language teaching. Foreign language annals, 51(1), 205-218. https://doi.org/10.1111/flan.12318

Khan, A., Egbue, O., Palkie, B., \& Madden, J. (2017). Active learning: Engaging students to maximize learning in an online course. Electronic Journal of E-Learning, 15(2), pp107115. Retrieved from https://academicpublishing.org/index.php/ejel/article/view/1824/1787

Kingsbury, M. (2015). Encouraging independent learning. In H. Fry, S. Ketteridge, \& S. Marshal (Eds.), A handbook for teaching and learning in higher education: Enhancing academic practice, (pp. 169-179). New York: Routledge

Lee, H. G. (2012). ESL learners' motivation and task engagement in technology enhanced language learning contexts. Washington State University. 
Luik, I. (2019). The use of kahoot! Game to acquire vocabulary competence. In The 7th Undergraduate Conference on ELT, Linguistic and Literature (2019) (p. 162). Retrieved from https://www.researchgate.net/profile/MariaRiyadini/publication/338501003_Proceedings_Undergraduate_Conference_2019/links /5e180dc54585159aa4c2f194/Proceedings-Undergraduate-Conference2019.pdf\#page $=162$

Manegre, M., \& Sabiri, K. A. (2020). Online language learning using virtual classrooms: an analysis of teacher perceptions. Computer Assisted Language Learning, 1-16. https://doi.org/10.1080/09588221.2020.1770290

Masoud, M. M., Aldahami, S. A., \& Aljehani, W. M. (2020). The effect of using kahoot! Webbased learning on efl secondary students'vocabulary learning. Retrieved from http://www.erint.savap.org.pk/PDF/Vol.9.1/ERInt.2020-9.1-02.pdf

Mansur, M., \& Fadhilawati, D. (2019). Applying Kahoot to improve the Senior High School students' vocabulary achievement. VELES Voices of English Language Education Society, 3(2), 164-173. http://dx.doi.org/10.29408/veles.v3i2.1591.g933

Metzger, K. J. (2015). Collaborative teaching practices in undergraduate active learning classrooms: A report of faculty team teaching models and student reflections from two biology courses. Bioscene, 41(1), 3-9. Retrieved from https://eric.ed.gov/?id=EJ1103875

Ministry of Education Malaysia (2013). Malaysia Education Blueprint 2013-2025. Putrajaya: Ministry of Education Malaysia. Retrieved from https://www.moe.gov.my/menumedia/media-cetak/penerbitan/dasar/1207malaysia-education-blueprint-2013-2025/file

Ministry of Education. (2017). National Education Policy (ed 4). Putrajaya: Ministry of Education Malaysia. Retrieved from https://www.pmo.gov.my/2019/07/nationaleducation-policy/

Nguyen, N. C. T., \& Nguyen, T. T. (2020). Non-Language-Major Students' Autonomy in Learning English in Vietnam. Arab World English Journal (AWEJ) Volume, 11. Retrieved from https://ssrn.com/abstract=3705076

Nomass, B. B. (2013). The impact of using technology in teaching English as a second language. English language and literature studies, 3(1), 111. http://dx.doi.org/10.5539/ells.v3n1p111

Nurhasanah, F. (2020). The Effectiveness of Socrative Application for Formative Assessment in Teaching Vocabulary at SMA Muhammadiyah 1 Ponorogo (Doctoral dissertation, IAIN PONOROGO). Retrieved from http://etheses.iainponorogo.ac.id/id/eprint/11252

Pershukova, O., Nikolska, N., \& Vasiukovych, O. (2020). Fostering students' autonomy in learning English in nonlinguistic university. SHS Web of Conferences, 75, 03007. Retrieved from https://easychair.org/publications/preprint/B6jx

Plump, C. M., \& LaRosa, J. (2017). Using Kahoot! in the Classroom to Create Engagement and Active Learning: A Game-Based Technology Solution for eLearning Novices. Management Teaching Review, 2(2), 151-158. https://doi.org/10.1177\%2F2379298116689783

Prasangani, K. S. (2019). Digital Platforms to Motivate English Learning Among Young Learners in Sri Lanka. GARI International Journal of Multidisciplinary Research, 5(3), 1-5. Retrived from 
http://multidisciplinaryjournal.globalacademicresearchinstitute.com/images/volume6-issue

Quiroz, M. F., Gutiérrez, R., Rocha, F., Valenzuela, M. P., \& Vilches, C. (2021). Improving English Vocabulary Learning through Kahoot!: A Quasi-Experimental High School Experience. Teaching English with Technology, 21(2), 3-13. Retrieved from https://www.ceeol.com/search/article-detail?id=945093

Rakangthong, S., \& Yimwilai, S. (2020) The Effects of Using Digital Game Resources to Enhance EFL Students' English Vocabulary Knowledge at Phimanphitthayasan School, Satun, Thailand. Retrived from https://rsucon.rsu.ac.th/proceedings

Razak, N., Ab Jalil, H., \& Ismail, I. (2019). Challenges in ICT integration among Malaysian public primary education teachers: The roles of leaders and stakeholders. International Journal of Emerging Technologies in Learning (iJET), 14(24), 184-205. Retrieved from https://www.learntechlib.org/p/217039/

Sanosi, A. B. (2018). The effect of Quizlet on vocabulary acquisition. Asian Journal of Education and e-learning, 6(4). Retrieved from www.ajouronline.com

Setiawan, M. R., \& Wiedarti, P. (2020). The effectiveness of Quizlet application towards students' motivation in learning vocabulary. Studies in English Language and Education, 7(1), 83-95. https://doi.org/10.24815/siele.v7i1.15359

Singhavi, C., \& Basargekar, P. (2019). Barriers Perceived by Teachers for Use of Information and Communication Technology (ICT) in the Classroom in Maharashtra, India. International Journal of Education and Development using Information and Communication Technology, 15(2), 62-78. Retrieved from https://eric.ed.gov/?id=EJ1220774

Son, J. B. (2011). Online tools for language teaching. TESL-EJ, 15(1), 1-12. Retrieved from http://www.tesl-ej.org/

Taylor, B., \& Reynolds, E. (2018, September). Building vocabulary skills and classroom engagement with Kahoot. In 26th Korea TESOL int=,u[;ernational conference (p. 89). Retrieved from https://koreatesol.org/sites/default/files/pdf_publications/KOTESOL.2018-Extended.Summaries..pdf\#page $=89$

Valentín, A., Mateos, P. M., González Tablas, M. M., Pérez, L., López, E., \& García, I. (2013). Motivation and learning strategies in the use of ICTs among university students. Computers \& Education, 61, 52-58. https://doi.org/10.1016/j.compedu.2012.09.008

Vurdien, R. (2020). Using Socrative Student Response System to Learn Phrasal Verbs. Journal of Foreign Language Education and Technology, 6(1). https://orcid.org/0000-00026011-5606

Waer, H. (2021). Using gamification in EFL vocabulary learning and learners' attitudes toward gamification use. . 547-570,2(22.2. https://dx.doi.org/10.21608/jsre.2021.54341.1236

Waluyo, B. (2018). Promoting self-regulated learning with formative assessment and the use of mobile app on vocabulary acquisition in Thailand. Indonesian Journal of English Language Teaching and Applied Linguistics, 3(1), 105-124. Retrieved from http://www.ijeltal.org/index.php/ijeltal

Yarahmadzehi, N., \& Goodarzi, M. (2020). Investigating the Role of Formative Mobile Based Assessment in Vocabulary Learning of Pre-Intermediate EFL Learners in Comparison 
INTERNATIONAL JOURNAL OF ACADEMIC RESEARCH IN PROGRESSIVE EDUCATION AND

DEVELOPMENT

Vol. 10, No. 3, 2021, E-ISSN: 2226-6348 @ 2021 HRMARS

with Paper Based Assessment. Turkish Online Journal of Distance Education, 21(1), 181196. https://doi.org/10.17718/tojde.690390

Ying, H. (2010). The school of teacher education English IV. A Study of L2 Vocabulary Learning Strategies

Yot-Domínguez, C., \& Marcelo, C. (2017). University students' self-regulated learning using digital technologies. International Journal of Educational Technology in Higher Education, 14(1), 1-18. Retrieved from

https://educationaltechnologyjournal.springeropen.com/articles/10.1186/s41239-

017-0076-8 